\title{
Exploring the thin line between misinformation and facts in the era of COVID-19 in selected border counties of Kenya
}

\author{
Stephen Oloo Ajwang1*(i), Enock Mac'Ouma² \\ ${ }^{1}$ Department of information science and informatics, School of Information Communication and Media Studies, Rongo University, Rongo Town, \\ Kenya \\ 2Department of Communication, Media and Journalism, School of Information Communication and Media Studies, Rongo University, Rongo \\ Town, Kenya
}

\begin{tabular}{|c|c|}
\hline Article Info & A B S T R A C T \\
\hline $\begin{array}{l}\text { Article type: } \\
\text { Research }\end{array}$ & \multirow{2}{*}{$\begin{array}{l}\text { Introduction: Information seeking behavior of the affected populations } \\
\text { during a pandemic is believed to significantly influence the way the } \\
\text { population manages the epidemic and curb its spread. This study sought to } \\
\text { identify and profile reliable sources of information that the residents of } \\
\text { Migori and Homa-Bay Counties in Kenya could use to curb the spread of } \\
\text { COVID-19 virus and enhance efficient management of risks associated with } \\
\text { the pandemic. }\end{array}$} \\
\hline $\begin{array}{l}\text { Article History: } \\
\text { Received: 2021-01-26 } \\
\text { Accepted: 2021-02-21 } \\
\text { Published: 2021-04-18 }\end{array}$ & \\
\hline $\begin{array}{l}\text { Department of information science } \\
\text { and informatics, School of } \\
\text { Information Communication and } \\
\text { Media Studies, Rongo University, } \\
\text { Rongo Town, Kenya }\end{array}$ & $\begin{array}{l}\text { Material and Methods: A survey method was used in which quantitative } \\
\text { data was generated through administration of online questionnaires to } 250 \\
\text { participants which were purposively selected. Data was analyzed using SPSS } \\
\text { version } 20 \text { and results presented in form of tables and graphs. A survey } \\
\text { method was used in which quantitative data was generated through } \\
\text { administration of online questionnaires to } 250 \text { participants which were } \\
\text { purposively selected. Data was analyzed using SPSS version } 20 \text { and results } \\
\text { presented in form of tables and graphs. }\end{array}$ \\
\hline Email:soloo@rongovarsity.ac.ke & \multirow{2}{*}{$\begin{array}{l}\text { Results: The study found out that the top } 3 \text { frequently used sources } \\
\text { information was television, official government press releases and social } \\
\text { media. The study also found out that there was high correlation between the } \\
\text { sources that were frequently used and their perceived credibility with a } \\
\text { coefficient of } 2=0.8426 \text {. English was the most preferred language for use in } \\
\text { sharing information. Further, the respondents preferred to receive } \\
\text { information based on how to protect self and the family. }\end{array}$} \\
\hline $\begin{array}{l}\text { Keywords: } \\
\text { COVID-19 } \\
\text { Infodemic } \\
\text { Information } \\
\text { Health Communication } \\
\text { Risk Communication }\end{array}$ & \\
\hline & $\begin{array}{l}\text { Conclusion: To counter the spread of misinformation, the study has } \\
\text { therefore profiled information sources and recommended that television, } \\
\text { official government press releases and properly managed social media } \\
\text { should be used to package and share relevant COVID-19 information to } \\
\text { reach the target population. }\end{array}$ \\
\hline
\end{tabular}

Cite this paper as:

Oloo Ajwang S, Mac'Ouma E. Exploring the thin line between misinformation and facts in the era of COVID-19 in selected border counties of Kenya. Front Health Inform. 2021; 10: 73. DOI: 10.30699/fhi.v10i1.276

\section{INTRODUCTION}

COVID-19 is a respiratory infectious disease which was initially discovered in Wuhan city of China between October and December of 2019 when a cluster of severe pneumonic cases first emerged. COVID-19 has infected 12,041,795 globally, 509,584 in Africa and 8,528 in Kenya [1]. The virus has resulted in a long-lasting global pandemic, which has been characterized by high death rates, economic meltdown with a projection of contracting the global economy by $3 \%$ and pushing about 49 million people into extreme poverty by end of the year 2020 []], and precipitating overwhelmed healthcare systems []ㅡ. Burns et al. [ 4 ] argue that besides crating the biggest challenge on the public health system across the globe, the pandemic has brought the normal life to a halt.

Due to lack of approved vaccines, the World Health Organisation (WHO) has recommended regular hygiene measures such as washing of hands, social distancing, avoiding touching of eyes, mouth and nose, good respiratory hygiene, isolation, and quarantine as some of the measures to help contain the spread of the virus []‥ In Kenya, COVID-19 
situation has rapidly evolved with the highest number of infections and deaths in comparison to other East African Countries [1]]. This situation is attributed to Kenya's strategic location and its critical role in the region as a commercial hub with intense cross border trade. Experts also argue that the reason Kenya continues to register more Covid-19 infections than her neighbors is the number of tests conducted every twenty-four hours.

In all pandemic situations, accurate information is key to helping curb spread, stigmatization and allow efficient management practices by the affected individuals and communities. Previous studies such as Young et al. [] ] have confirmed that interpersonal and media spirals shape health behaviour. Since the first case of COVID-19 was announced in Kenya on $12^{\text {th }}$ March 2020, there has been an insatiable thirst for information and updates on the pandemic. According to AMREF Health Africa [7], information and updates that majority usually search for relate to the following questions: what is corona virus? How is COVID-19 spread? What are the symptoms of Covid19 infection? What should I do when I develop the symptoms of the disease? How is COVID-19 treated? How dangerous is COVID-19, which groups of persons are most vulnerable to contracting the disease? How can stigma relating to COVID-19 be managed? As a result of the high demand for answers to the aforesaid questions, there is, a relentless search for, and rapid exchange of information from sources such as word of mouth, radio, newspapers, television and social media.

The health emergency caused by COVID-19 has led to an increased clamour for information as the public tries to understand how the virus spreads, how to stay safe, and what to do if one suspects to have been exposed. The heightened appetite for COVID-19 information has also been exacerbated by the people's desire to keep up to date with guidelines provided by national and/or county government for WHO updates, travel information, education, reopening of the economy among others.

This heightened need for information or news has presented a new context for the publication and spread of fake information about the pandemic []. It is therefore critical that effective information production and consumption habits that could serve to counter misinformation and influence positive online behaviors are enhanced.

\section{Infodemic}

According to WHO, infodemic is an excessive amount of information about a problem which makes it difficult to identify a solution and is normally spread through misinformation, disinformation and rumours during disasters and emergencies [9]. The misinformation normally spread faster influencing behaviour and raising anxiety among the public and thus critically alter the public healthcare system [10]. For the case of COVID-19 pandemic, infodemic is aggravated by the global scale of the health emergency, and propagated by the interconnectedness of the world, influencing the way and speed at which information is disseminated and consumed through social media platforms and other channels [9].

The United Nations (UN) has warned against the proliferation of misinformation about the virus with WHO indicating that fake news has been spreading faster and easily than the virus complicating further the health emergency response. The emergence of new communication platforms and access-enabling technology, such as social media and cell phones that connect networks of people who often share similar opinions and cultural beliefs, has exacerbated and amplified this problem [11].

According to Department of Global Communication, of the UN, some of the reported cases of misinformation include individuals claiming to be selling fake coronavirus cures, the origin of the virus, transmission patterns; available treatments, prophylactics and cures, effectiveness and impact of interventions by health authorities, home remedies such as ginger and garlic for the prevention of the virus, the virus cannot survive in hot weather, taking a high dose of chloroquine medication can protect against the virus, symptoms to look out for, the spreading mechanism among others [12, $\underline{13}]$. Criminals have also exploited the crisis arising from Covid-19 pandemic to breach data privacy and protection guidelines. Accordingly, there have been reported cases of cyber-attack on hospitals' critical information systems, cyber-frauds and violation of individual data privacy and confidentiality. The researchers from Carnegie Melon University found out that out of the 200 million tweets about COVID$19,46 \%$ appeared to have been sent by computer bots [14].

The situation has been made worse by the contributions of politicians to the misinformation conundrum. In an article published by the University of New South Wales newsroom, Bartlett says, "in Africa as commentators suggest, threats to life do not only come in the form of the virus. They arrive in the guise of Africa's political leaders who have also contributed to misinformation and opportunism to an already dangerous cocktail of issues." The expert argues that misinformation, opportunism and a myriad of day-to-day issues may dwarf the threat of COVID-19 in Africa [1]․

Some of the widely shared fake news about the pandemic on the continent include false claims that the virus is a biological weapon created by China against other superpowers like the US [1]ㅡ, use of herbs such as garlic and ginger to treat the virus [17]; 5G technology, not COVID-19 was behind several 
deaths in Nigeria [18]; Bill Gates making USD 200 billion from the vaccine for the virus [19]; that drinking alcohol can ward off the virus and that eating high-alkaline foods can eliminate COVID-19.

\section{Information overload}

The concept of information overload dates back to Gutenberg period when the printing machine was first invented and a lot of print material overwhelmed human capacity to comprehend in an entire lifetime $[\underline{20}, \underline{21}]$. The invention of digital technologies such as the internet especially social media such as Facebook, Google, Pinterest, Tencent, Twitter, TikTok, and YouTube further proliferated in many folds the volume of information in varied formats reaching users over time [2ㄹ. For instance, a search of the word "information" in Google returned 19.5 billion results on $8^{\text {th }}$ July 2020 far much higher than what an average person could come across in his lifetime. Casero-Ripolles [23] also found out that the consumption of news from pre-COVID-19 to the pandemic era rose from $60 \%$ to $92 \%$.

Information overload can negatively affect people's wellbeing, decision making, innovation and productivity [21]. So far, over 360 million videos on COVID-19 have been uploaded on YouTube, and about 19,200 articles have been published in Google Scholar since the pandemic started. In March, around 550 million tweets included the terms coronavirus, corona virus, covid19, covid-19, covid_19, or pandemic [13].

Risk communication and community engagement: Information for preparedness and response during emergencies

Covello [24], defines risk communication as, "the process of exchanging information among interested parties about the nature, magnitude, significance, or control of a risk". Janoske et al [25] posit that all communities need a way to communicate about present, emerging, and evolving risks. The WHO, [26], on the other hand, describes risk communication as the range of information capacities required through the preparedness, response and recovery phases of a serious public health event to encourage informed decision making, positive behaviour change and the maintenance of trust. This description underscores other definitions of the subject, including that of Covello.

In numerous case studies in crisis risk communication events, audiences have misinterpreted messages, warnings have failed to warn, false rumors have been generated, multiple sources have given false information, populations have not been reassured, and the media has sensationalized the story [27-29]. Findings by Lep et al. [30] confirm that the level of trust in sources of information also plays an important role in motivating the engagement in self-protective behaviors.

From these discussions, the importance of, and the need for effective risk communication during the COVID-19 pandemic is clear and need not be overemphasized. According to an Inter-Agency Rapid Assessment Report published by the Kenya Red Cross Society in 2015 [31], approximately $30 \%$ of the populations of Migori and Homa-Bay Counties cannot read and write. This scenario has a high likelihood of influencing information seeking behaviours, as well as decision making on COVID-19 prevention and management. In this regard, effective risk communication remains of extreme importance to the residents of Migori and Homa-Bay Counties.

\section{Research gap}

Based on the above literature, infodemic is a major challenge to outbreak response, it presents an opportunity to identify and adopt new preparedness and response tools. The UN Secretary-General, António Guterres in his Twitter handle indicated that infodemic of misinformation has become an enemy as that of COVID-19 and called for the promotion of facts science, hope and solidarity [32]. This position has been reinforced by the, Director-General of WHO, Dr. Tedros Adhanom Ghebreyesus who said, "we are not just fighting an epidemic; we're fighting an infodemic" [33]. These facts present the potential negative effect of infodemic during health emergencies. Therefore, there is need to counter the spread of misinformation and promote access to the appropriate information at the right time and in the right format during rapidly evolving pandemic such as COVID-19. In this attempt, WHO has created a myth buster and live question and answer interviews on its website, on social channels and media to help filter the facts from misinformation. Equally, United Nations Development Program (UNDP) has created an International Fact-Checking Network while Google removes misleading information in its platform and Twitter fact checks tweets. Further, WHO organized the first infodemiology conference held in June and July 2020 to discuss how infodemic has affected the world and reflection on how it can be managed [34]. Also, there has been $70 \%$ reduction in the number of forwarded messages upon the introduction of limited sharing of information on WhatsApp [35]. While WHO recognizes that infodemic cannot be totally eliminated, more needs to be done to influence the public, especially in the local region who may not have access to information available online to seek the right information on COVID-19 from the right sources.

\section{Objectives}

The objective of this study was to:

- Describe the information seeking behaviour of the publics in Migori and Homa-Bay 
Counties since the onset of the COVID-19 pandemic in Kenya.

- Profile sources of information which the publics can rely on for information and updates on COVID-19.

- Inform the target population on sources of COVID-19 information and updates with a view to making them better managers of the risk associated with the pandemic.

\section{Conceptual model}

The study sought to explore the symbiotic relationship between the information seeking behavior and management of the COVID-19 pandemic by residents of Migori and Homa-Bay Counties. In view of this, the researchers settled on the CRAAP test. CRAAP (Currency, Relevance, Authority, Accuracy, Purpose) is a popular tool among academic librarians for instructing students in resource evaluation [흐].

\section{MATERIAL AND METHODS}

The study adopted a survey method to explore the information-seeking behaviour of the public and profile information sources that could be relied on to effectively manage the COVID-19 pandemic. The study was carried out over a period of 30 days in the month of July 2020. Quantitative data was collected through questionnaires administered on a total of 250 respondents who were purposively sampled. The respondents included community healthcare workers, ministry of health officials at the County and National levels, opinion leaders, residents of Migori and Homa Bay Counties, journalists and IT experts, front line health workers and ministry of interior and coordination of national government in Migori and Homa-Bay counties.

The study population was chosen as a representative sample based on their knowledge on COVID-19 pandemic. Purposive sampling was used because it was an efficient way of enlisting a few participants to take part in a survey where the larger population is generally concerned about the pandemic, and therefore constantly participate in the search for and sharing of related information. The researchers recognize that the sample may not have been an acceptable representation of the population of the study. However, it allowed an in-depth understanding of key research concerns such as sources of information, basic knowledge of how COVID-19 virus is transmitted, beliefs, perceptions and how the disease is managed etc. Data was analysed using SPSS tool and results presented in tables and graphs.

\section{RESULTS}

\section{Demography of the population}

With regards to the demography of the respondents, there were more males (54.9\%) than females (45.1\%), as to the age, the population was predominantly young with those below 25 years old accounting for more than $60 \%$. Concerning the level of education, the population was generally learned with everybody having at least an A-Level qualification.

\section{Awareness about COVID-19 disease}

It is of interest that all the respondents knew what COVID-19 disease was. However, when it comes to assessing the depth of knowledge of the diseases, the respondents seemed to know more about symptoms of the disease at $82 \%$ followed by people at high risk of $81 \%$. On the contrary, there was an average knowledge with regards to general awareness of the disease such as susceptible age group, race and weather conditions (63\%). In some cases, there was total lack of knowledge on specific questions under transmission (such as eating garlic, interaction with pets, delivering grocery) even though its weighted average was $69 \%$. For instance, some respondents See Table 1.

Table 1: Depth of knowledge on various aspects of Covid-19 disease

\begin{tabular}{|l|c|}
\hline Knowledge & Weighted Average \\
\hline Prevention/Protection & $80 \%$ \\
\hline Transmission & $69 \%$ \\
\hline Symptoms & $82 \%$ \\
\hline General Awareness & $63 \%$ \\
\hline Treatment & $70 \%$ \\
\hline Incubation Period & $74 \%$ \\
\hline People at High Risk & $81 \%$ \\
\hline
\end{tabular}

Also, it was noted that all together, those aged above 58 appeared to have better understanding of the disease (88\%) than those between the ages of 46-58 years old as shown in Table 2 .

Table 2: Depth of knowledge based on age

\begin{tabular}{|l|c|}
\hline Age & Weighted Average \\
\hline Below 25 & $77 \%$ \\
\hline $26-35$ & $80 \%$ \\
\hline $36-45$ & $80 \%$ \\
\hline $46-58$ & $63 \%$ \\
\hline Above 58 & $88 \%$ \\
\hline
\end{tabular}

Information seeking behaviour of the public since the onset of the COVID-19 pandemic in Kenya

From the study, it was noted that $63 \%$ of respondents frequently updated their knowledge about COVID-19 disease with the highest number of respondents reporting that they first heard about the diseases from television at $92 \%$ followed by Social media (e.g. 
Facebook, Twitter, YouTube, WhatsApp) at $86.3 \%$ and official government press releases at $76.5 \%$. The source that the respondents least heard the information about COVID-19 disease from was community mobilizer at $17.6 \%$ (Fig 1 ).

Sources of information which the public relies on for information and updates on COVID-19

To stay informed about COVID-19, the respondents refer to various information sources at different extent. Table 3 indicates the most frequent response (mode) per information source and the percentage of the population accounting for such a response.

In a scale of 1-6, 6 being exceedingly high and 1 as extremely low, the proportion of the population composing the mode, perceives the respective information sources in terms of information credibility.

Further analysis was made by correlating the frequency mode against perceived credibility as illustrated in Fig 2. The high degree of correlation at $\mathrm{R}^{2}=0.8426$ is indicative that the respondents referred more frequently to information sources that they had higher perceived credibility on.

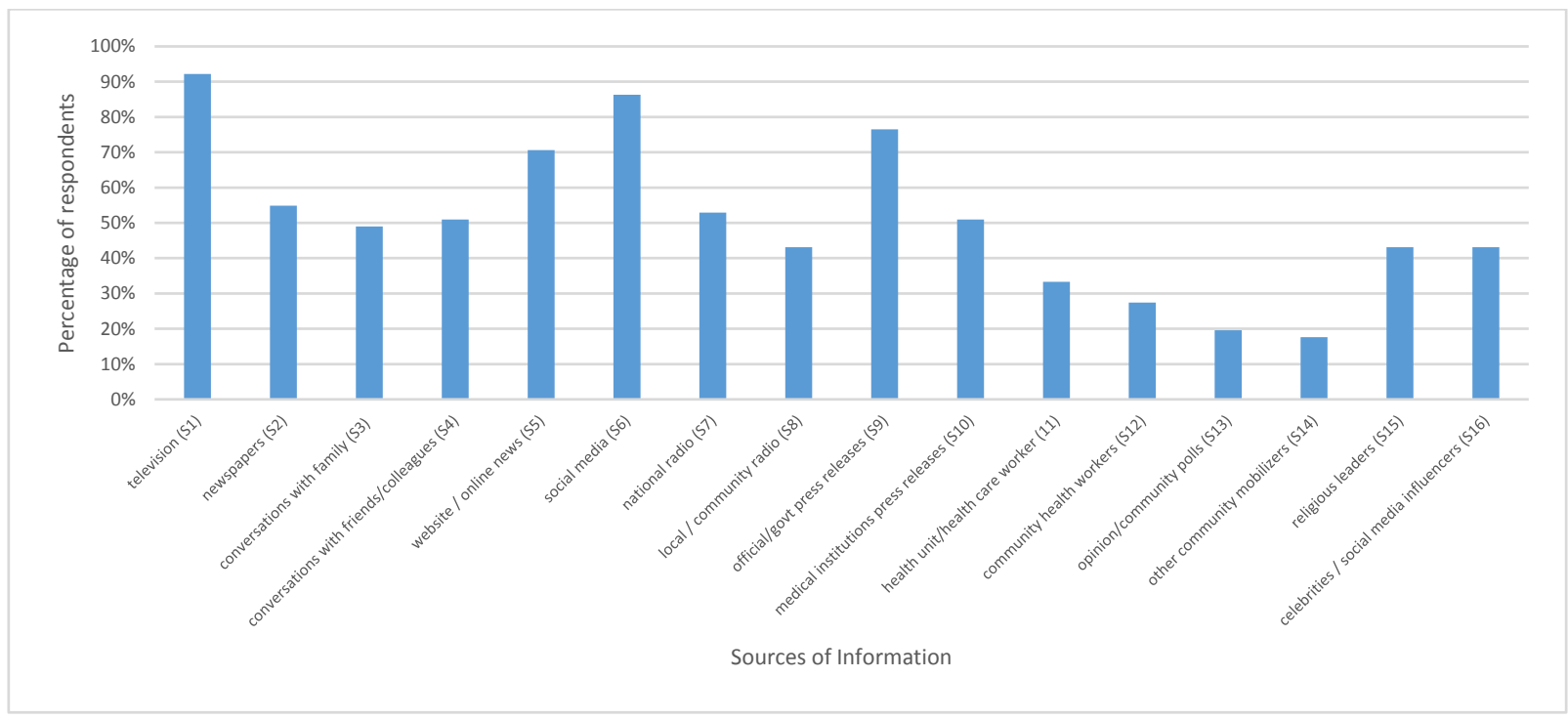

Fig 1: Sources where the public first heard information on COVID-19

Table 3: Response per information source

\begin{tabular}{|l|c|c|c|}
\hline \multicolumn{1}{|c|}{ Source } & Mode & Percentage of the respondents & Average perception \\
\hline Television & very often & $37 \%$ & 5.263 \\
\hline Newspapers & sometimes & $39 \%$ & 4.000 \\
\hline Conversations with family & very often & $29 \%$ & 4.600 \\
\hline Conversations with friends/colleagues & very often & $31 \%$ & 4.563 \\
\hline Website / online news & often & $31 \%$ & 3.875 \\
\hline Social media & very often & $41 \%$ & 4.476 \\
\hline National radio & sometimes & $39 \%$ & 4.050 \\
\hline Local / community radio & sometimes & $39 \%$ & 3.850 \\
\hline Official, government press releases & very often & $37 \%$ & 4.947 \\
\hline Medical institutions press releases & sometimes & $35 \%$ & 3.556 \\
\hline Health unit / health care worker & sometimes & $25 \%$ & 3.308 \\
\hline Community health workers & never & $27 \%$ & 3.214 \\
\hline Opinion / community polls & never & $35 \%$ & 2.556 \\
\hline Other community mobilisers & never & $29 \%$ & 2.467 \\
\hline Religious leaders & sometimes & $41 \%$ & 3.333 \\
\hline Celebrities and social media influencers & sometimes & $33 \%$ & 3.471 \\
\hline
\end{tabular}




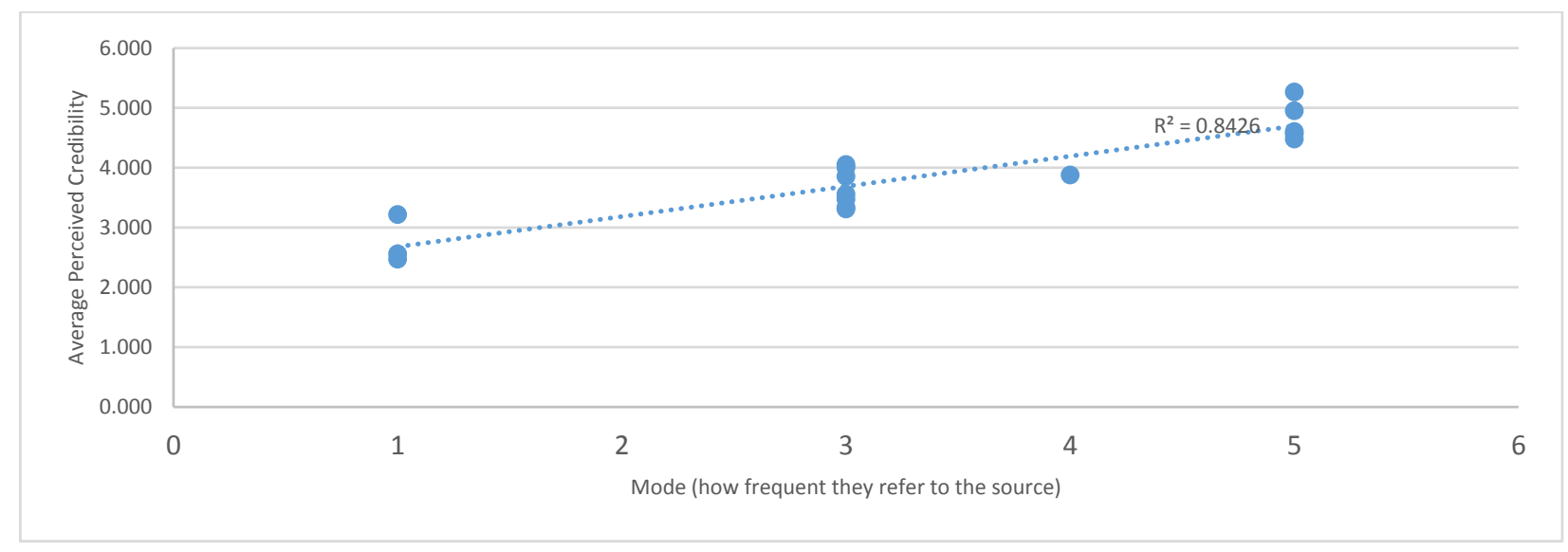

Fig 2: Frequency of use against perceived credibility of the information source

To rank the information sources based on frequency of use and perceived quality, a weight was factored in as represented by the number of respondents that made up the mode. Television (S1), Social Media (S6) and official government press releases (S9) rated the highest as shown in Fig 3.

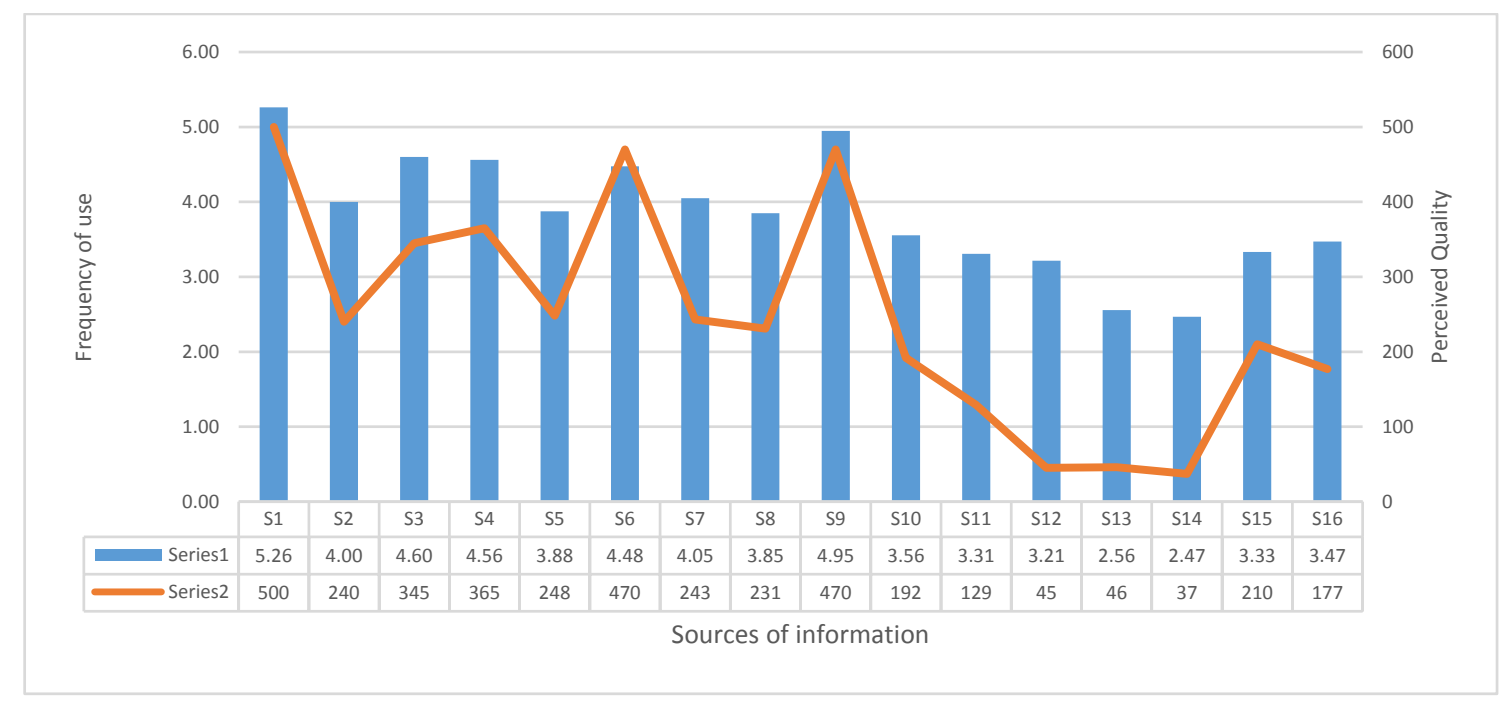

Fig 3: Frequency of use and perceived quality of information

Type of information required by the respondents

The study also tried to find out the type of information that was required the most by the respondents. The findings are as shown in Fig 4 which indicates that, how to protect self and family against the covid-19 accounted for the highest need at $75 \%$ followed by Scientific progress in the development of a vaccine at $63 \%$ symptoms of covid19 disease at $59 \%$ while the least sough information was child education at $10 \%$. This could be attributed to the fact that most respondents were young and may have not had children.

\section{Language preference}

In order to package the information is the sources referred by the respondents, the study sought to understand the preferred language of communication. The preferences are as shown in Fig 5. Most respondents indicated that they required information to be delivered in English language at $88 \%$ confirming the fact that most respondents were predominantly educated. 


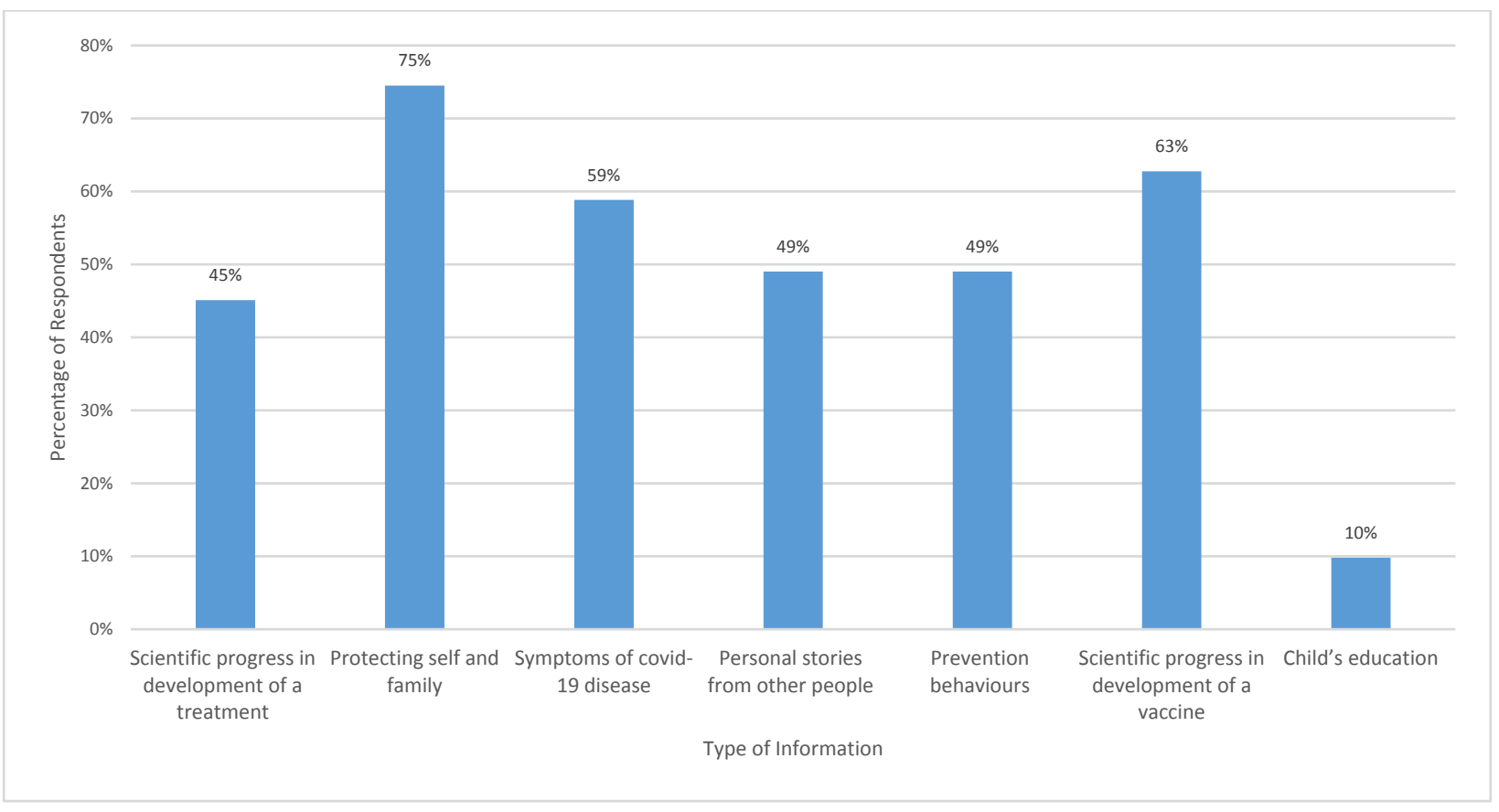

Fig 4: Type of information

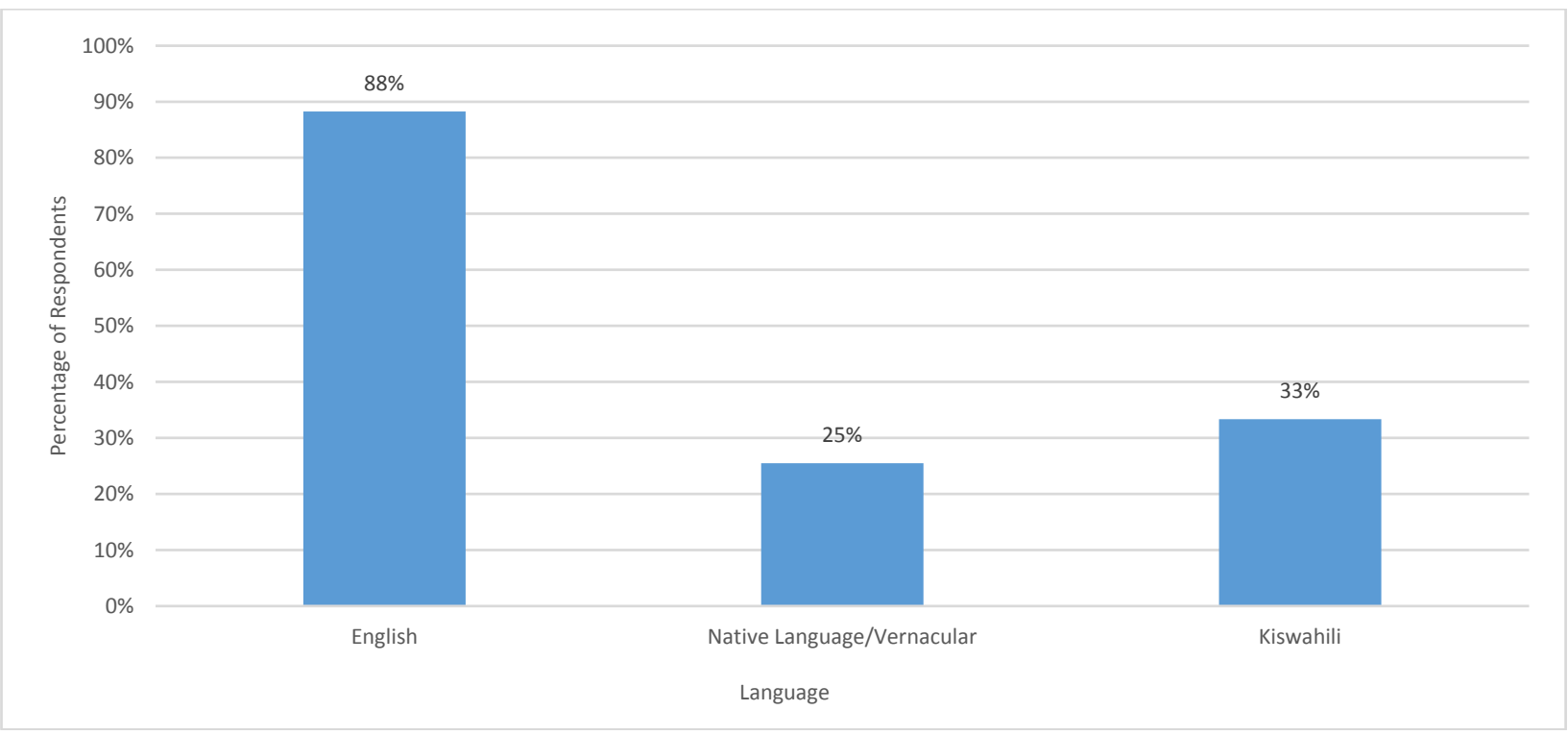

Fig 5: Language preference

\section{DISCUSSION}

The study sought to describe the information seeking behaviour of the publics in Migori and Homa-Bay Counties and to profile sources of information which the publics can rely on for information and updates on COVID-19. From the findings, it was noted that the public was generally aware of COVID-19 disease given the massive nature of the pandemic, the global traction and attention it has received and its impact on livelihoods. Despite, this some of the respondents were not adequately informed about COVID-19 thus some provided answers such as use of ginger and garlic for the prevention of the transmission of the virus, the virus cannot survive in hot weather, taking a high dose of chloroquine medication. This is in agreement with some of the trending forms of misinformation as already reported by $\mathrm{WHO}[\underline{26}]$ and PAHO [13]. It also confirms findings by Dhanani et al. [37] that suggests that trust and news consumption can pose critical barriers to health literacy and foster negative prejudicial responses that further undermine public health efforts surrounding the COVID-19 pandemic.

The study also found out that the most trusted and widely used source of information was television closely followed by official government press releases and social media. These sources were 
perceived as credible, accurate and timely. Moloney [38] points out that COVID-19 has also brought the public-service mission of journalism to the forefront and notes that the New York times, for example have made COVID-19 information exceedingly accessible to information seekers. However, as argued by Hauer et al. [의], information on social media about COVID19 protective measures must come from trusted health organizations or experts that have the most up to date information. The finding that television is among the most widely used source of information could be attributed to the fact that television presented information in multimedia form which could be seen and listened to given the low literacy levels as shown by the Inter-Agency Rapid Assessment Report by Kenya Red Cross Society [31]. The government releases were trusted because of the socio-political nature of the society while social media ranked high given the demographic spread of the population.

Shalvee et al. [40] confirm that in this COVID-19 crisis, media played a very significant role in making people aware about the situation and encourage them to take positive action. The study also revealed that the respondents required more information on how to protect themselves and family from getting the disease, development of vaccine and the disease symptoms, which could be obtained from mainstream media in Kenya. This could be attributed to the fact that the respondents were pre-occupied with the need for information to fight the spread of COVID-19, avoid the risk associated with it and reduce its overall impact. This finding is in agreement with the update from AMREF Health Africa [7] on the type of questions asked by the public with regard to COVID-19. This will help in reducing cases of information overload.

It was also noted that most respondents required the information to be packaged and delivered in English signifying that the respondents were literate and required information delivered in its original form from World Health Organization or Ministry of Health taking into consideration the potential loss of information when translated to native language.

These finding also reveal that there was a lot of misinformation about COVID-19 before and within the period of study.

\section{CONCLUSION}

The global health crisis caused by COVID-19 diseases has presented unprecedented demand for information leading to rise of misinformation hence the need to filter credible information and trusted sources. The study has therefore profiled and recommended that television, official government press releases and properly managed social media should be used to package and share the relevant COVID-19 related information to reach the target population.

The study recommends that policy makers, government institutions and all the stakeholders in the healthcare sector should package and share specific and updated information related to COVID19 through television, social media and official government press releases The information should be compiled in English and should be accessible and readily available.

\section{What is known about this topic}

- Health emergency caused by COVID-19 has led to increased clamour for information as the public tries to understand how the virus spreads, how to stay safe, and what to do if one suspects to have been exposed.

- Infodemic has potential negative effect on the public during health emergencies and thus impedes interventions.

\section{What this study adds}

- $\quad$ The study describes the information seeking behaviour of the publics in Migori and Homa-Bay Counties since the onset of the COVID-19 pandemic in Kenya.

- It also profiles sources of information which the publics can rely on for information and updates on COVID-19.

- Finally the study informs the target population on sources of COVID-19 information and updates with a view to counter the spread of misinformation and promote access to the appropriate information at the right time and in the right format during rapidly evolving pandemic such as COVID-19

\section{AUTHOR'S CONTRIBUTION}

All authors contributed to the literature review, design, data collection and analysis, drafting the manuscript, read and approved the final manuscript.

\section{CONFLICTS OF INTEREST}

The authors declare no conflicts of interest regarding the publication of this study.

\section{FINANCIAL DISCLOSURE}

No financial interests related to the material of this manuscript have been declared. 


\section{REFERENCES}

1. Africa Centers for Disease Control and Prevention. Outbreak brief: COVID-19 pandemic [Internet]. 2020 [cited: 1 Oct 2020]. Available from: https://au.int/sites/default/files/documents/39162 -doc-africacdc_covidbrief_25august20_en1.pdf

2. International Monetary Fund. World economic outlook: The great lockdown [Internet]. 2020 [cited: 1 Oct 2020]. Available from: https://www.imf.org/en/Publications/WEO

3. Ferretti L, Wymant C, Kendall M, Zhao L, Nurtay A, Abeler-Dörner L, et al. Quantifying SARS-CoV-2 transmission suggests epidemic control with digital contact tracing. Science. 2020; 368(6491): eabb6936. PMID: 32234805 DOI: 10.1126/science.abb6936 [PubMed]

4. Burns D, Dagnall N, Holt M. Assessing the impact of the COVID-19 pandemic on student wellbeing at universities in the United Kingdom: A conceptual analysis. Frontiers in Education. 2020; 5: 582882.

5. World Health Organization. Coronavirus disease (COVID-19) advice for the public [Internet]. 2020 [cited: 19 Aug 2020]. Available from: https://www.who.int/emergencies/diseases/novelcoronavirus-2019/advice-for-public

6. Young DG, Bleakly A. Ideological health spirals: An integrated political and health communication approach to COVID-19 interventions. International Journal of Communication. 2020; 14: 3508-24.

7. Amref COVID-19 Africa Information Centre. Learn about Coronavirus [Internet]. 2020 [cited: 31 Aug 2020]. Available from: https://amref.org/coronavirus/?gclid=EAIaIQobChM IvbbL3-

nE6wIVhIxRCh319ABpEAAYASAAEgIkUfD_BwE

8. Orso D, Federici N, Copetti R, Vetrugno L, Bove $T$. Infodemic and the spread of fake news in the COVID19-era. Eur J Emerg Med. 2020; 27(5): 327-8. PMID: 32332201 DOI: 10.1097/MEJ.0000000000000713 [PubMed]

9. World Health Organization. Managing the COVID-19 infodemic: Promoting healthy behaviours and mitigating the harm from misinformation and disinformation [Internet]. 2020 [cited: 5 Oct 2020]. Available from: https://www.who.int/news/item/23-09-2020managing-the-covid-19-infodemic-promotinghealthy-behaviours-and-mitigating-the-harm-frommisinformation-and-disinformation

10. Ali S. Combatting against Covid-19 \& misinformation: A systematic review. Human Arenas. 2020; 2020: 116.

11. Sell TK, Hosangadi D, Trotochaud M. Misinformation and the US Ebola communication crisis: analyzing the veracity and content of social media messages related to a fear-inducing infectious disease outbreak. BMC Public Health. 2020; 20(1): 550. PMID: 32375715 DOI: 10.1186/s12889-020-08697-3 [PubMed]

12. Department of Global Communications. UN tackles 'infodemic' of misinformation and cybercrime in COVID-19 crisis [Internet]. 2020 [cited: 15 Aug 2020]. Availale from: https://www.un.org/en/uncoronavirus-communications-team/un-tackling\%E2\%80\%98infodemic\%E2\%80\%99-

misinformation-and-cybercrime-covid-19

13. Pan American Health Organization. Understanding the infodemic and misinformation in the fight against COVID-19 [Internet]. 2020 [cited: 15 Oct 2020]. Available from: https://www.paho.org/en/documents/understandin g-infodemic-and-misinformation-fight-against-covid19

14. Grothaus M. $45 \%$ of Twitter accounts posting COVID19 messages are likely bots [Internet]. 2020 [cited: 5 Oct 2020]. Available from: https://www.fastcompany.com/90508552/45-oftwitter-accounts-posting-covid-19-messages-arelikely-bots-study-says.

15. Bartlett A. Coronavirus in Africa: A complex reality [Internet]. 2020 [cited: 6 Aug 2020]. Available from: https://newsroom.unsw.edu.au/news/socialaffairs/coronavirus-africa-complex-reality. Published on 24th April 2020

16. Ahinkorah BO, Ameyaw EK, Hagan JE, Seidu AA, Schack T. Rising above misinformation or fake news in Africa: Another strategy to control COVID-19 spread. Frontiers in Communication. 2020; 5: 45.

17. Pennycook G, McPhetres J, Zhang Y, Lu JG, Rand D. Fighting COVID-19 misinformation on social media: Experimental evidence for a scalable accuracy nudge intervention. Psychol Sci. 2020; 31(7): 770-80. PMID: $32603243 \quad$ DOI: $10.1177 / 0956797620939054$ [PubMed]

18. BBC News. COVID-19 in Africa: Fighting fake news about coronavirus [Internet]. 2020 [cited: 23 Aug 2020]. Available from: https://www.bbc.co.uk/news/resources/idte7e3acde-9cdf-4b53-b469-ef6e87a66411

19. AFP Fact Check. Fighting myths about coronavirus in Africa [Internet]. 2020 [cited: 15 Oct 2020]. Available from: https://factcheck.afp.com/fighting-mythsabout-coronavirus-africa

20. Sadiku MNO, Shadare AE, Musa SM. Information overload: Causes and cures. Journal of Multidisciplinary Engineering Science and Technology. 2016; 3(4): 4540-2.

21. Hemp P. Death by information overload [Internet] 2009 [cited: 7 Jul 2020]. Available from: https://hbr.org/2009/09/death-by-informationoverload

22. Zarocostas J. How to fight an infodemic. Lancet. 2020; 395(10225): 676. PMID: 32113495 DOI: 10.1016/S0140-6736(20)30461-X [PubMed]

23. Casero-Ripolles A. Impact of COVID-19 on the media system: Communicative and democratic consequences of news consumption during the outbreak. El Professional de La Información. 2020; 29(2): e290223.

24. Covello VT. Risk communication: An emerging area of 
health communication research. Annals of the International Communication Association. 1992; 15(1): 359-73.

25. Janoske M, Brooke L, Ben S. Understanding risk communication best practices: A guide for emergency managers and communicators. Report to Human Factors/Behavioral Sciences Division, Science and Technology Directorate, U.S. Department of Homeland Security. START; 2012.

26. World Health Organization. General information on risk communication [Internet]. 2018 [cited: 21 Aug 2020]. Available from: https://www.who.int/riskcommunication/background/en/

27. Engdahl E, Lidskog R. Risk, communication and trust: Towards an emotional understanding of trust. Public Understanding of Science. 2014;23(6): 703-717. https://doi.org/10.1177/0963662512460953

28. Vaughan E, Tinker T. Effective health risk communication about pandemic influenza for vulnerable populations. Am J Public Health. 2009; 99(Suppl 2): S324-32. PMID: 19797744 DOI: 10.2105/AJPH.2009.162537 [ PubMed]

29. Glik DC. Risk communication for public health emergencies. Annu Rev Public Health. 2007; 28: 3354. $\quad$ PMID: $17222081 \quad$ DOI: 10.1146/annurev.publhealth.28.021406.144123 [PubMed]

30. Lep Z, Babnik K, Beyazoglu KH. Emotional response and self-protective behaviour within days of the COVID-19 outbreak: The promoting role of information credibility. Front Psychol. 2020; 11: 1846. PMID: 32849087 DOI: 10.3389/fpsyg.2020.01846 [PubMed]

31. Limbu M, Wanyagi L, Ondiek B, Munsch B, Kiilu K. Kenya inter-agency rapid assessment mechanism (KIRA): A bottom-up humanitarian innovation from Africa. Procedia Engineering. 2015; 107: 59-72.

32. Guterres A. Infodemic of misinformation has become an enemy as that of Covid-19 and called for the promotion of facts science, hope and solidarity
[Internet]. 2020 [cited: 5 Oct 2020]. Available from: https://twitter.com/antonioguterres/status/124374 8397019992065?lang=en

33. Ghebreyesus TA. We are not just fighting an epidemic; we're fighting an infodemic [Internet]. 2020 [cited: 1 Dec 2020]. Available from: https://twitter.com/WHO/status/12286839497964 70784

34. World Health Organization. 1st WHO infodemiology conference [Internet]. 2020 [cited: 31 Aug 2020]. Available from: https://www.who.int/newsroom/events/detail/2020/06/30/defaultcalendar/1st-who-infodemiology-conference

35. Singh M. WhatsApp's new limit cuts virality of 'Highly Forwarded' messages by $70 \%$ [Internet]. 2020 [cited: 27 Apr 2020]. Available from: https://social.techcrunch.com/2020/04/27/whatsa pps-new-limit-cuts-virality-of-highly-forwardedmessages-by-70/.

36. Abbey LB. What does bad information look like? Using the CRAAP test for evaluating substandard resources. Issues in Science and Technology Librarianship. 2018; 88: 7.

37. Dhanani LY, Franz B. The role of news consumption and trust in public health leadership in shaping COVID-19 knowledge and prejudice. Front Psychol. 2020; 11: 560828. PMID: 33192827 DOI: 10.3389/fpsyg.2020.560828 [PubMed]

38. Moloney K. All the news that's fit to push: The New York times company and transmedia daily news. International Journal of Communication. 2020; 14: 4683-702

39. Hauer MK, Sood S. Using social media to communicate sustainable preventive measures and curtail misinformation. Frontiers in Psycology. 2020; 11: 568324.

40. Shalvee, Sambhav S. Role of mass media \& communication during pandemic COVID-19. International Journal of Creative Research Thoughts. 2020; 8(5): 3786-90. 